\title{
The effects of building management practices on residential property prices in Hong Kong
}

Received (in revised form): 6th November, 2008

\section{Yung Yau}

is currently conducting research and lecturing in City University of Hong Kong. Before joining the university, he practiced building control in the Buildings Department, the Government of Hong Kong Special Administrative Region. His research interests include housing studies, urban renewal, heritage conservation, real estate economics and finance and building performance assessment.

\section{Daniel Chi Wing Ho}

is a qualified building surveyor and a Fellow of both the Hong Kong Institute of Surveyors and the Royal Institution of Chartered Surveyors. He is currently an associate professor and the Head of the Department of Real Estate and Construction, The University of Hong Kong. His research interests and expertise are in facility performance assessment, development control and facility management.

Correspondence: Yung Yau, Department of Public and Social Administration, City University of Hong Kong, Tat Chee Avenue, Kowloon, Hong Kong; Tel: +852 2788 8958; Fax: + 85227888926

\begin{abstract}
Building management and maintenance has gained its importance after a series of disastrous building-related incidents in Hong Kong. To facilitate the management of an apartment building, homeowners usually form an owners' association among themselves and/or appoint an external property management agent (PMA) to manage the building on their behalf. Empirical studies found that the involvement of these bodies was conducive to a better-performing built environment, and that premium was added to betterperforming properties. Yet, these studies often took the formation of owners' association and engagement of external PMA in a building as dichotomous variables in exploratory models, and thus ignored the variations in the adopted building management practices in different buildings even with the same building management setting. Making use of the data collected from two previous research projects, a hedonic price analysis was carried out to study whether specific building management practices added value to the properties concerned. The analysis results indicated that properties in buildings with good documentations (eg keeping of as-built architectural drawings and incident records), thoughtful emergency planning (eg presence of emergency plan and regular fire drills) and property-all-risk insurance coverage were sold at a premium, ceteris paribus. Policy and practical implications then follow. Journal of Building Appraisal (2009) 4, 157-167. doi:10.1057/jba.2008.42
\end{abstract}

\section{Keywords:}

building management, apartment buildings, hedonic price model, Hong Kong

\section{INTRODUCTION}

Recent literature such as Yiu (2007) and Yau (2008) has highlighted the long-lasting problem of building neglect in Hong Kong. Painful consequence of such neglect is best illustrated by the localised outbreak of the Severe Acute Respiratory Syndrome in Amoy 
Gardens in 2003. In spite of this lesson, building-related incidents such as tragic fires and falling building fabrics are common in the city. To sustain a healthy and safe urban environment in Hong Kong, the local government launched two public consultations on the approaches to ensure that the building stock in the territory could be properly serviced and how a building care culture could be fostered (Housing, Planning and Lands Bureau, 2004, 2005). Yet, we need to understand the root of the current predicaments in building management and maintenance before a sensible solution can be devised.

Fong (1984) attributed the building problems to the high-rise high-density development pattern adopted in Hong Kong. In multi-storey residential or apartment buildings, communal areas (eg entrance lobbies and communal corridors) and facilities (eg water supply systems and fire service installations) are co-owned by individual homeowners, and all owners are jointly responsible for the management and maintenance of these shared parts (Nield, 1990; Bailey and Robertson, 1997; Yip and Forrest, 2002). However, Bengtsson $(1998,2001)$ and Walters (2002), founding on the game theory and concept of transaction cost respectively, expounded residents' participation or investment in the common good with regard to building management as unlikely.

To facilitate the coordination among individual homeowners in managing the shared parts of a building, some organisation for building management is needed. The Home Affairs Department (2001) suggested the homeowners to actively participate in the matters of building management by forming statutory owners' associations. At the same time, the homeowners can appoint external property management agents (PMAs) to manage the building on their behalf. While there is a growing body of research examining the effects of building management on building performance (eg Ho et al., 2006, 2007) and residents' satisfaction (Paris, 2006), little work has focused on the relationship between property management and property price.

In this light, this study aims to fill up this research gap by investigating which building management practices add value to properties in Hong Kong. By means of hedonic price analysis, the transaction data of 189 apartment buildings in Hong Kong were studied. We found that property value was enhanced by practices like keeping as-built architectural drawings and incident records, taking out property-all-risk insurance for common areas, setting out emergency plans and conducting regular fire drills. The findings in this study have far-reaching practical and policy implications.

\section{LITERATURE REVIEW}

\section{Roles of building management bodies}

The significance of property or building management to building conditions and residents' wellbeings has been well documented. Given the design and construction are up to standard, buildings are usually of good performance when newly built. As a physical asset, a property is always subject to wear and tear (Hui, 2005). Therefore, proper maintenance and management is indispensable for keeping the building in serviceable conditions (DeCarlo, 1997; Choy, 1998; Chung, 1999). To facilitate the management of multi-storey buildings in Hong Kong, the Home Affairs Department advocated the formation of incorporated owners (IO) and the appointment of external PMAs. By virtue of the Building Management Ordinance (Chapter 344 of the Laws of Hong Kong), an IO is a legal entity set up to act legally on behalf of all owners of a multi-storey building or development. Unlike other types of owners' or residents' associations such as owners' committees and mutual aid committees, the formation and operations of an IO was backed up and, at the same time, bound by the ordinance and/or deed of mutual covenant 
(Nield, 1990). The Building Management Ordinance confers the power to the IO to enforce the resolutions made in the general owner meetings (Home Affairs Department, 2001).

Besides, IO is powered to monitor the services provided by the external PMA, and terminate the service contracts if the agent does not perform satisfactorily. On the whole, the regular meetings held by the IO provide a platform for the homeowners to air grievances, and facilitate decision making on building management issues (Kent et al., 2002).

No matter whether an owners' association exists in an apartment building or not, homeowners can appoint an external PMA to manage the building on their behalf. The responsibilities of a PMA vary across buildings, and may include provision of security and cleansing services, and assisting homeowners in convening meetings and coordinating activities (Home Affairs Department, 2001). Besides, the external PMAs are responsible for keeping up physical conditions of buildings through preventive measures and routine maintenance. They also attend to the financial wellbeing of building management structure under their charge through fiscal planning and budget controls (Fong, 1984).

Buildings with statutory owners' associations were found to have fewer problems and better conditions for the building (Ng, 2004; Ho et al., 2006; Wan et al., 2006). Lai and Ho (2001) argued that external PMAs, with better know-how in using legal means, can help check the problem of unauthorised building works. On the contrary, a weakprincipal-strong-agent situation may occur when powers are delegated to the management committee of an owners' association or an external PMA. Although the committee members should act on behalf of their principals (ie the homeowners), they may make decisions that are beneficial to themselves at the costs of other owners (Walters and Kent, 2000). Such kind of rent-seeking behaviour is best illustrated by the proliferation of corruption cases in building management in Hong Kong. The Independent Commission Against Corruption received 978, 822 and 972 corruption reports involving building management in 2005, 2006 and 2007, respectively (The Government of the Hong Kong Special Administrative Region, 2008). Among some 2,000 private-sector corruption reports received in 2007, 40 per cent were related to building maintenance works.

\section{Building management and property value}

There has been plenty of research dedicated to the relationship between building characteristics and property price, especially in residential properties. For example, Vandell and Lane (1989) and Chau et al. (2004) discovered that properties with better designs attracted higher values. Robinson (1946) and Jimenez (1983) found that betterconditioned properties were rewarded with higher value. Nonetheless, the association between property value and building management has not been extensively investigated. Studying 15 residential developments in Hong Kong, Hastings et al. (2006) evidenced that the presence of PMA or statutory owners' association in a building was found to be a significant predictor of property value. Lau (2005) found that the properties managed by an external PMA had value added if that agent was certified under the ISO system.

Yet, these previous studies on the value enhancement effects of building management are not free from methodological flaws. For example, Hastings et al. (2006) took building management dichotomously in the exploratory model: using whether a statutory owners' association was formed and whether an external PMA was engaged as proxies of building management. Likewise, Lau (2005) only concerned whether the PMA was accredited by the ISO. These dichotomous definitions are misleading because even with the same building management structure, buildings could have different building management practices in place. That means the management practices or even outputs vary across buildings so it is not precise to use the existence of one particular type of building 
management body as the sole indicator in building management studies. Value enhancement effects of individual management practices remain to be demonstrated because it is more insightful to know that which practices are valued by the market players and which are not.

\section{ANALYTICAL FRAMEWORK AND METHODOLOGY}

As aforementioned, there is little in literature in terms of robust and detailed studies examining which management practices add values to the managed properties. In this regard, hedonic price model was adopted in this study for the exploratory analysis. According to Rosen's (1974) seminal work, hedonic price model can extract the implicit price of property attributes from property transaction prices. As such, it can be employed to estimate the value enhancement effects of various building management practices. With the loss of generality, the price of a property $(P)$ can be expressed as a function $f($.$) of the$ physical characteristics of the property $(X)$, management practices executed in the building $(M)$, location-related factors $(L)$, the time when the property was transacted $(T)$ and unknown parameters $(\varphi)$, or mathematically

$$
P R I C E=f(X, L, M, T ; \varphi)
$$

\section{Model specification}

Since the functional form of $f($.$) is not known a priori, a semi-log specification with$ quadratic terms for continuous variables was used for estimation because this functional form has been widely supported (eg Hogarty, 1975; Bajic, 1993). The generic model in Equation (1) was thus specified as:

$$
\begin{aligned}
& \ln \text { PRICE }_{i t}=\alpha_{0}+\alpha_{1} A G E_{i}+\alpha_{2} A G E_{i}^{2}+\alpha_{3} F_{L O O R} \\
& +\alpha_{4} \text { FLOOR }_{i}^{2}+\alpha_{5} \text { SIZE }_{i}+\alpha_{6} \text { SIZE }_{i}^{2} \\
& +\alpha_{7} \mathrm{UNIT}_{i}+\alpha_{8} \mathrm{UNIT}_{i}^{2}+\alpha_{9} \mathrm{TKT}_{i} \\
& +\alpha_{10} P E_{i}+\alpha_{11} M K_{i}+\alpha_{12} Y M T_{i}+\alpha_{13} J D_{i} \\
& +\alpha_{14} T_{S T}+\alpha_{15} T_{i}+\alpha_{16} N P_{i}+\alpha_{17} M_{T R} \\
& +\alpha_{18} M_{T} R_{i}^{2}+\beta_{1} G B P_{i}+\beta_{2} B S P_{i} \\
& +\beta_{3} F S_{-} P L A N_{i}+\beta_{4} T P L_{i}+\beta_{5} P A R_{i} \\
& +\beta_{6} I_{N C I D E N T}+\beta_{7} \text { SINK }_{-} \text {FUND }_{i} \\
& +\beta_{8} E M E R \_P L A N_{i}+\beta_{9} R E S_{-} S U R V E Y_{i} \\
& +\beta_{10} \text { FIRE_DRILL } L_{i}+\beta_{11} \text { FIRE_DRILL }_{i}^{2} \\
& +\phi T I M E_{i t}+\varepsilon_{i}
\end{aligned}
$$

where $\alpha_{s}(s=0,1,2, \ldots, 18), \beta_{w}(w=1,2, \ldots, 11)$ and $\varphi$ (a vector of coefficients) are coefficients to be estimated, and $\varepsilon$ is the stochastic term. The variables incorporated in Equation (2) are described in Table 1.

The first set of coefficients (ie $\alpha_{s}$ ) measures the marginal effects of the inborn property characteristics such as building age, floor level, floor area, development scale, distance 
Table I: Descriptions of the variables used in Equation (2)

\begin{tabular}{|c|c|}
\hline Variable & Description \\
\hline$P R I C E_{i t}$ & The transaction price of property $i$ at time $t$ (measured in $\mathrm{HK} \$$ million) \\
\hline & $\begin{array}{l}\text { ce age of property } i \text { at time } t \text {, which equals the difference between the date of the issue of the } \\
\text { cupation permit and the date of the transaction (measured in years) }\end{array}$ \\
\hline$F L O O R_{i}$ & e floor level of property $i$ \\
\hline$S I Z E_{i}$ & The gross floor area of property $i$ (measured in square feet) \\
\hline$U_{N} T_{i}$ & The number of domestic units present in the residential development comprising property $i$ \\
\hline$T K T_{i}$ & A dummy variable which equals $I$ if property $i$ is located in Tai Kok Tsui, and zero if otherwise \\
\hline$P E_{i}$ & A dummy variable which equals I if property $i$ is located in Prince Edward, and zero if otherwise \\
\hline & dummy variable which equals $I$ if property $i$ is located in Mong Kok, and zero if otherwise \\
\hline$Y M T_{j}$ & dummy variable which equals I if property $i$ is located in Yau Ma Tei, and zero if otherwise \\
\hline$j D_{i}$ & A dummy variable which equals $I$ if property $i$ is located in Jordan, and zero if otherwise \\
\hline TST $_{i}$ & A dummy variable which equals I if property $i$ is located in Tsim Sha Tsui, and zero if otherwise \\
\hline $\mathrm{TH}_{i}$ & A dummy variable which equals I if property $i$ is located in Tin Hau, and zero if otherwise \\
\hline$N P_{i}$ & dummy variable which equals I if property $i$ is located in North Point, and zero if otherwise \\
\hline$M T R_{i}$ & The distance between property $i$ and the nearest Mass Transit Railway station (measured in metres) \\
\hline$G B P_{i}$ & $\begin{array}{l}\text { A dummy variable which equals I if a set of architectural drawings of the subject building has been kept } \\
\text { by the building management body for record, and zero if otherwise }\end{array}$ \\
\hline$B S P_{i}$ & $\begin{array}{l}\text { A dummy variable which equals } I \text { if a set of building service plans of the subject building has been kept } \\
\text { by the building management body for record }\end{array}$ \\
\hline FS_PLAN ${ }_{i}$ & $\begin{array}{l}\text { A dummy variable which equals I if a fire safety plan has been provided to the residents of the subject } \\
\text { building, and zero if otherwise }\end{array}$ \\
\hline$T P L_{i}$ & $\begin{array}{l}\text { A dummy variable which equals I if third-party liability insurance has been taken out for the common } \\
\text { parts of the subject building, and zero if otherwise }\end{array}$ \\
\hline$P A R_{i}$ & $\begin{array}{l}\text { A dummy variable which equals I if property-all-risk insurance has been taken out for the common } \\
\text { parts of the subject building }\end{array}$ \\
\hline INCI & $\begin{array}{l}\text { A dummy variable which equals I if incident records have been kept by the building management body, } \\
\text { and zero if otherwise }\end{array}$ \\
\hline SINK_FUND & $\begin{array}{l}\text { A dummy variable which equals I if there is remaining sinking fund available in the subject building, and } \\
\text { zero if otherwise }\end{array}$ \\
\hline EMER_PL & $\begin{array}{l}\text { A dummy variable which equals I if an emergency plan is in place for the subject building, and zero if } \\
\text { otherwise }\end{array}$ \\
\hline RES_SURVEY & $\begin{array}{l}\text { A dummy variable which equals I if regular resident surveys on the safety and hygienic conditions of the } \\
\text { building are conducted, and zero if otherwise }\end{array}$ \\
\hline FIRE_ & The number of fire drills conducted every month in the subject building \\
\hline$T I M E_{i t}$ & A monthly dummy variable that equals I when property $i$ was transacted at time $t$, and zero if otherwise \\
\hline
\end{tabular}

from the mass transit system and location on property price. Regarding the locational dummies, properties situated in Quarry Bay were taken as the reference location or base. All these characteristics were controlled in the model. Besides, time dummies set on a monthly basis were used to control for the possible effect of time on the variations in property transaction price because panel data on property transactions were used and market conditions might change over time. Meanwhile, the second coefficient set (ie $\beta_{w}$ ) measures the effects of marginal effects of various building management practices on property price. A total of ten building management practices were investigated in this study.

\section{Building management practices investigated}

To facilitate building management and maintenance, documentations like keeping record plans, maintaining incident records and seeking feedbacks from the occupants on building conditions are essential. For example, a complete set of updated records or as-built drawings on architectural and building services designs is useful for future maintenance and renovation (Cheng, 1998; Home Affairs Department, 2001). It provides details of the systems used in a building, such as the capacity of its electricity supply system and the routing of its cables. This can make decision making during emergency maintenance easier. Also, record drawings are solid references for identifying unauthorised building works and other irregularities in a building. 
In addition, keeping track of these incidents such as falling building fabrics, fires, and interruptions of power supply is advantageous for the homeowners and property managers of a building. A similar attitude towards the importance of incident records has been widely shared by researchers in the field of occupational safety (eg Koornneef and Hale, 1997; Hakkinen, 1999). The analyses based on these incident records provide building stakeholders with insights into the aspects of building management that warrant more attentions, and valuable information for property managers to prioritise improvement works.

As for residents' feedbacks, they are essential for the evaluation of the work of the building management bodies. Very often, the feedbacks in residential premises are obtained systematically from occupant surveys, which provide a formal channel for occupants to give comments to management. This evaluation mechanism is important for the continuous improvement of building performance (Zimring and Reizenstein, 1980). Upon observing and addressing the comments in the surveys, the management bodies concerned can help raise the satisfactory level of occupants and the conditions of the building.

Apart from documentations, emergency preparedness is another critical aspect of building management because we need to ensure that management is able to react calmly, and all occupants are able to evacuate orderly to safety in case of an emergency (Malhotra, 1987). To enhance the emergency preparedness of the management body in a building, an emergency or contingency plan should be formulated (Carighead, 2003). An emergency plan sets out what the building management body should do in the event of an emergency, and how they should handle and recover from it (Egbuji, 1999). At the same time, residents of an apartment building should familiarise themselves with the direction and routing of the means of escape in buildings and always be prepared for a quick evacuation (Information Services Department, 1997). This issue should not be ignored because buildings designed and constructed with excellent means of escape do not guarantee that their occupants would know where the exits are located. To aid in the familiarisation, evacuation plans should be provided to occupants and/or posted in conspicuous positions in the buildings. Besides, regular fire drills are indispensable to provide training or rehearsal to occupants (Home Affairs Department, 2001).

Lastly, building management system relies on the availability of financial resources for emergencies to be effective. For instance, it is very difficult to raise or collect money from every individual homeowner for the cost of emergency repair works in common areas of a building. Therefore, the availability of sinking fund in a building reduces the response time for emergencies and unexpected circumstances, guaranteeing the future upkeep of a building. Similarly, the Home Affairs Department (2001) recommended building management bodies to take out third-party liability and property-all-risk insurances for the common parts of their buildings. The first type of insurance indemnifies the homeowners from claims for compensation and associated legal costs as a result of personal injury to or the death of a third party caused by the negligence of the insured while the second type usually covers losses or damages to the common parts or facilities of a building due to fire, storm, flood or other malicious acts. With a view to lower premiums for the insurances, the homeowners are self-motivated to keep their buildings in serviceable conditions.

Since it is widely accepted that the building management practices investigated in this study have positive impacts on the building conditions, we envisage that these practices would be positively valued by the market players. Along this line of thought, we 
hypothesise that all coefficients $\beta_{w}(w=1,2, \ldots, 11)$ should be statistically significant and positive.

\section{DATA DESCRIPTIONS}

The investigation of the effects of various building management practices on property price was made possible with the Building Health and Hygiene Index and Building Safety and Conditions Index research projects funded by the Research Grants Council and the University of Hong Kong. In the two projects, the details of which can be found in Wong et al. (2006) and Ho et al. (2008), apartment buildings in Hong Kong were benchmarked with reference to their health and safety performance using a tailormade assessment framework. The assessment covered different quality aspects, namely architectural design, building service provisions, external environment, operations and maintenance, and management arrangements. Therefore, information regarding the management practices in the assessed buildings is available for data analysis in this study.

In total, data of 189 apartment buildings in the Yau Tsim Mong and Eastern Districts assessed in 2004 and 2005 respectively were used for this study. There were altogether 3,057 transactions in the 189 buildings between January 2002 and December 2005. Information on the transaction prices and particulars of the transacted properties (eg age, floor level and floor area) was obtained from the Economic Property Research Centre. Descriptive statistics of the continuous variables are described in Table 2.

\section{ANAYLSIS RESULTS AND DISCUSSION}

The estimation results of the hedonic price analysis are shown in Table 3 . The adjusted $R$ squared was about 0.74 , indicating that about 74 per cent of the variations in property prices could be explained by the variations in the dependent variables. We found that all the control variables, namely AGE, FLOOR, SIZE, UNIT and MTR, had significant (at least at the 10 per cent level) non-linear effects on the transaction prices of the properties under investigation. Except for North Point, transaction prices in all districts deviated significantly with those in Quarry Bay, ceteris paribus.

As for the ten building management practices, six of them were found to significantly affect property prices. Keeping general building plans added 12.9 per cent premium to the concerned properties (significant at the 1 per cent level). Properties in buildings covered by property-all-risk insurance policies were sold at a price 3.6 per cent higher than those uncovered (significant at the 1 per cent level). Besides, 7.5 (significant at the 1 per cent level) and 2.1 per cent (significant at the 10 per cent level) of value were added to the transacted properties if incident records were documented and emergency plan was set out, respectively. Moreover, the analysis results indicate that the frequency of regular fire drills had a positive relationship with the property price (significant at the 10 per cent level), given that it exceeded 0.56 time per month. All the results above confirm with our

Table 2: Descriptive statistics of the continuous variables

\begin{tabular}{lcccc}
\hline Continuous variable & Maximum & Mean & Minimum & Standard deviation \\
\hline PRICE (in HK\$ million) & 9.18 & 1.20 & $5 \times 10^{-3}$ & 0.79 \\
AGE (in years) & 47 & 25.21 & 3 & 9.65 \\
FLOOR & 40 & 10.92 & 1 & 6.91 \\
SIZE (in square feet) & 1,921 & 562.38 & 227.14 & 193.96 \\
UNIT & 12,896 & 518.15 & 3 & $1,660.44$ \\
MTR (in metres) & $1,136.52$ & 310.11 & 13.32 & 270.37 \\
FIRE_DRILL (number of times per month) & 1 & 0.17 & 0 & 0.36 \\
\hline
\end{tabular}


Table 3: The regression results of the hedonic price models

\begin{tabular}{|c|c|c|c|c|}
\hline \\
\hline \multicolumn{5}{|c|}{$\begin{array}{l}\text { Dependent variable: } \ln (\mathrm{PRICE}) \\
\text { Independent variable }\end{array}$} \\
\hline Constant & -1.5659 & 0.0814 & $-|9.248|$ & $0.0000 * * *$ \\
\hline AGE & 0.0087 & 0.0037 & 2.3746 & 0.0176 *** \\
\hline$A G E^{2}$ & -0.0006 & $7.34 \times 10^{-5}$ & -7.8908 & $0.0000 * * *$ \\
\hline FLOOR & 0.0137 & 0.0022 & 6.1065 & 0.0000 **** \\
\hline$F L O O R^{2}$ & -0.0002 & $7.64 \times 10^{-5}$ & -2.0824 & $0.0374 * *$ \\
\hline SIZE & 0.0030 & 0.0002 & 17.4200 & $0.0000 * * *$ \\
\hline$S I Z E^{2}$ & $-8.89 \times 10^{-7}$ & $1.26 \times 10^{-7}$ & -7.0708 & $0.0000 * * *$ \\
\hline UNIT & 0.0001 & $1.53 \times 10^{-5}$ & 8.8057 & 0.0000 **** \\
\hline UNIT ${ }^{2}$ & $-7.65 \times 10^{-9}$ & $1.04 \times 10^{-9}$ & -7.3572 & $0.0000 * * *$ \\
\hline$T K T$ & -0.2489 & 0.0597 & -4.1675 & $0.0000 * * *$ \\
\hline$P E$ & -0.1461 & 0.0309 & -4.7288 & $0.0000 * * *$ \\
\hline MK & -0.1246 & 0.0421 & -2.9625 & $0.003 \mathrm{I} * * *$ \\
\hline YMT & -0.0773 & 0.0296 & -2.6083 & $0.0091 * *$ \\
\hline JD & -0.1197 & 0.0366 & $-3.267 \mid$ & $0.0011^{* * * *}$ \\
\hline TST & 0.1553 & 0.0336 & 4.6192 & $0.0000 * * *$ \\
\hline$T H$ & 0.0650 & 0.0254 & 2.5552 & $0.0107 * *$ \\
\hline$N P$ & -0.0070 & 0.0261 & -0.2693 & 0.7877 \\
\hline MTR & 0.0003 & $9.29 \times 10^{-5}$ & 3.1970 & $0.0014 * * *$ \\
\hline$M T R^{2}$ & $-2.64 \times 10^{-7}$ & $1.01 \times 10^{-7}$ & -2.6273 & 0.0087 *** \\
\hline GBP & 0.1286 & 0.0279 & 4.6112 & $0.0000 * * *$ \\
\hline$B S P$ & -0.0502 & 0.0151 & -3.3192 & $0.0009 * * *$ \\
\hline FS_PLAN & -0.0148 & 0.0118 & -1.2503 & 0.2113 \\
\hline$T P L$ & 0.0124 & 0.0189 & 0.6559 & 0.5119 \\
\hline PAR & 0.0360 & 0.0126 & 2.8534 & $0.0044 * * *$ \\
\hline INCIDENT & 0.0752 & 0.0170 & 4.4095 & $0.0000 * * *$ \\
\hline SINK_FUND & 0.0052 & 0.0140 & 0.3695 & 0.7118 \\
\hline EMER_PLAN & 0.0212 & 0.0126 & 1.6844 & $0.0922 *$ \\
\hline RES_SURVEY & -0.0226 & 0.0152 & -1.4860 & 0.1374 \\
\hline FIRE_DRILL & -0.3054 & 0.1648 & $-|.853|$ & $0.0640 *$ \\
\hline FIRE_DRILL ${ }^{2}$ & 0.2718 & 0.1635 & 1.6624 & $0.0965 *$ \\
\hline Adjusted $R$-squared & $0.740 \mathrm{I}$ & & $\begin{array}{l}\text { Durbin-Watson } \\
\text { statistic }\end{array}$ & 2.0202 \\
\hline F-statistics & II5.5240 & & Akaike info criterion & 0.3514 \\
\hline Prob(F-statistic) & 0.0000 & & $\begin{array}{l}\text { Number of observa- } 3 \\
\text { tions }\end{array}$ & 3,057 \\
\hline
\end{tabular}

Notes:

I. $* * *, * *$ and $*$ denote the estimated coefficients of the variables to be significant at the I, 5 and 10 per cent level, respectively. 2. The results for the time dummies were omitted, but are available upon request.

3. All coefficients were estimated with White's Heteroskedasticity-consistent standard errors.

expectations. Nevertheless, practices like provision of fire safety plan to the residents, taking out of third-party liability insurance, availability of sinking fund and regular resident surveys did not have any significant impacts on the property transaction price. Moreover, it is difficult to explain why properties in buildings with building services plans documented were generally sold at a 5 per cent discount (significant at the 1 per cent level), ceteris paribus.

Based on the empirical findings, we may conclude that not all building management practices currently adopted are positively valued by the housing market. The analysis results give practitioners insights into which management practices are valued most by the market players, helping them to formulate better business strategies. Also, if the value enhancement through the building management practices is well publicised in the society, a building care culture can be fostered by market forces. Homeowners are more willing to 
practice building management in their buildings with a view to the premium added to the value of their properties. On the other hand, warning signals are given to the public administrators if some management practices are considered essential by the government but were found to be insignificant determinant of property price. A gap exists between the government's aspirations and the market's valuation, and more resources should be directed to the education and promotion campaigns about the importance of these 'undervalued' practices. Alternatively, the government may need to think about making these practices mandatory or subsidising them.

Yet, some precautions should be taken in interpreting the relationships between property prices and building management practices. In spite of the wide varieties in the inborn characteristics of the buildings (eg age and development scale) under study, only properties in those buildings with transaction records were included in the sample. In fact, a total of 323 apartment buildings were assessed in the Building Health and Hygiene Index and Building Safety and Conditions Index projects. However, those buildings badly dilapidated had no transactions during the target study period so they were not included in the sample. In other words, potential sample selection bias may limit the generalisability of the research findings.

\section{CONCLUDING REMARKS}

Although many people thought that buildings managed by owners' associations and/or external PMAs should perform better, Walters and Kent (2000) posited the opposite because the committee members in the owners' associations and the external PMAs tended to make decisions which were beneficial to themselves. Other than these agency problems, building management and maintenance is sometimes hindered by the inactive owners' association (Housing, Planning and Lands Bureau, 2005). Worse still, rivalry may exist within owners' associations (Housing, Planning and Lands Bureau, 2004) or between homeowners and external PMAs. This will only worsen rather than relieve the building management problems. In this light, simply using the formation of owners' association and appointment of external PMA as proxies for building management in empirical analyses could generate misleading results. Against this background, we offered a preliminary study on the property-value enhancement effects of various building management practices in Hong Kong. We found that practices such as keeping as-built architectural drawings and incident records, taking out property-all-risk insurance for common areas, setting out emergency plans and conducting regular fire drills added value to properties.

The analysis results give market players, housing management practitioners and public administrators' insights into which management practices are valued most by the market. Regardless of the valuable insights provided, this study should be regarded only a starting point for studying this research topic. Further research is recommended to explore how the levels or dimensions of building management practices affect property value. To put it another way, management practices under investigation in this study were taken as dichotomous variables so information of their dimensions was ignored. In fact, explanatory factors such as TPL and PAR can be represented or measured in some other dimensions. For instance, instead of simply considering whether insurance policies have been taken out or not, we can look into the value of insurance coverage. It is a similar situation for the sinking fund. As a result of this adjustment, we can know how the value enhancement effects vary with the value of the insurance cover or sinking fund. Moreover, the value enhancement study can be extended to cover management practices such as implementation of planned maintenance and cleansing of public areas. 


\section{Acknowledgements}

An earlier version of this paper was submitted to the PM'2008 Conference held in Wuhan in November 2008. The work described in this paper was partially supported by a grant from City University of Hong Kong (Project No. 7200123). The authors also gratefully acknowledge the financial supports provided by the Research Grants Council of Hong Kong (HKU 7107/04E and 7131/05E) and the University of Hong Kong.

\section{References}

Bailey, N. and Robertson, D. (1997) Management of Flats in Multiple Ownership: Learning from Other Countries, Policy Press, Bristol.

Bajic, V. (1993) 'Automobiles and implicit markets: an estimate of a structural demand model for automobile characteristics', Applied Economics, 2, 541-551.

Bengtsson, B. (1998) 'Tenants' dilemma: on collective action in housing', Housing Studies, 13(1), 99-120.

Bengtsson, B. (2001) 'Solving the tenants' dilemma: collective action and norms of co-operation in housing', Housing, theory and Society, 17(4), 175-187.

Carighead, G. (2003) High-Rise Security and Fire Life Safety, Butterworth-Heinemann, Amsterdam.

Chau, K.W., Wong, S.K. and Yiu, C.Y. (2004) 'The value of the provision of a balcony in apartments in Hong Kong', Property Management, 22(3), 250-264.

Cheng, R.W.M. (1998) 'Property management', in Poon, T.N.T. and Chan, E.H.W. (eds) Real Estate Development in Hong Kong, Pace Publishing, Hong Kong, pp. 254-263.

Choy, Y.L. (1998) 'Building safety issues', in Buildings Department (ed.) Building Construction in Hong Kong, Buildings Department, Hong Kong, pp. 3-14.

Chung, B.H.K. (1999) 'Safety and health hazards in buildings', The Journal of Building Surveying, 1(1), 41-42.

DeCarlo, J.W. (1997) Property Management, Prentice-Hall, Upper Saddle River, NJ.

Egbuji, A. (1999) 'Risk management of organisational records', Records Management Journal, 9(2), 93-116.

Fong, P.K.W. (1984) The Management of High-Rise Residential Development in Hong Kong, Institute of Housing, Hong Kong Branch, Hong Kong.

Hakkinen, K. (1999) 'Risk reduction within companies by a better understanding of safety', Law and Insurance, 4(1/2), 51-54.

Hastings, E.M., Wong, S.K. and Walters, M. (2006) 'Governance in a co-ownership environment: the management of multiple-ownership property in Hong Kong', Property Management, 24(3), 293-308.

Ho, D.C.W., Chau, K.W., Cheung, A.K.C., Yau, Y., Wong, S.K., Leung, H.F., Lau, S.S.Y. and Wong, W.S. (2008) 'A survey of the health and safety conditions of apartment buildings in Hong Kong', Building and Environment, 43(5), 764-775.

Ho, D.C.W, Chau, K.W., Yau, Y. and Wong, S.K. (2007) 'An empirical study of unauthorized appendages in multi-storey residential buildings in Hong Kong', Proceedings of the Sixth China Urban Housing Conference, 26-28 March, Beijing, pp. 263-272.

Ho, D.C.W., Yau, Y., Wong, S.K., Cheung, A.K.C., Chau, K.W. and Leung, H.F. (2006) 'The effects of building management regimes on building performance in Hong Kong', Property Management, 24(3), 309-321.

Hogarty, T.F. (1975) 'Price-quality relations for automobiles: a new approach', Applied Economics, 7(1), 41-51. Home Affairs Department. (2001) Building Management, Home Affairs Department, Hong Kong.

Housing, Planning and Lands Bureau. (2004) Building Management and Maintenance: Public Consultation, Housing, Planning and Lands Bureau, Hong Kong.

Housing, Planning and Lands Bureau. (2005) Building Management and Maintenance: Public Consultation on Mandatory Building Inspection, Housing, Planning and Lands Bureau, Hong Kong.

Hui, E.Y.Y. (2005) 'Key success factors of building management in large and dense residential estates', Facilities, 23(1/2), 47-62.

Information Services Department. (1997) Fire Safety Guide, Government Printer, Hong Kong.

Jimenez, E. (1983) 'The magnitude and determinants of home improvement in self-help housing: Manila's Tondo Project', Land Economics, 59(1), 70-83.

Koornneef, F. and Hale, A. (1997) 'Learning from incidents at work', in Redmill, F. and Rajan, J. (eds) Human Factors in Safety-Critical Systems, Butterworth-Heinemann, Oxford, pp. 257-286. 
Kent, P., Merry, M. and Walters, M. (2002) Building Management in Hong Kong, LexisNexis, Hong Kong.

Lai, L.W.C. and Ho, D.C.W. (2001) 'Unauthorized structures in high-rise high-density environment', Property Management, 19(2), 112-123.

Lau, M.C.H. (2005) 'Property values and quality of property management in Hong Kong', Proceedings of the CRIOCM 2005 International Symposium on Advancement of Construction Management and Real Estate, 30 October-2 November, Hangzhou, pp. 469-476.

Malhotra, H.L. (1987) Fire Safety in Buildings, Building Research Establishment, Borehamwood.

Nield, S. (1990) 'Legal framework of deeds of mutual covenant', in Nield, S. and Sihombing, J. (eds) Multi-Storey Building Management, Hong Kong Law Journal, Hong Kong, pp. 1-25.

Ng, H.F. (2004) 'Hygienic determinants of residential buildings in Hong Kong', unpublished BSc Dissertation, Department of Real Estate and Construction, The University of Hong Kong, Hong Kong.

Paris, D.E. (2006) 'Impact of property management services on affordable housing residents in Atlanta, Georgia', Journal of Performance of Constructed Facilities, 20(3), 222-228.

Robinson, C.K. (1946) 'Relationship between condition of dwellings and rentals by race', The Journal of Land and Public Utility Economics, 22(3), 296-302.

Rosen, S. (1974) 'Hedonic prices and implicit markets: product differentiation in pure competition', The Journal of Political Economy, 82(1), 34-55.

The Government of the Hong Kong Special Administrative Region. (2008) 'Corruption reports involving building management', available at http://www.info.gov.hk/gia/general/200805/28/P200805280080.htm, accessed on 5 November 2008.

Vandell, K.D. and Lane, J.S. (1989) 'The economics of architecture and urban design: some preliminary findings', Journal of the American Real Estate and Urban Economics Association, 17(2), 235-265.

Walters, M. (2002) 'Transaction costs of collective action in Hong Kong high rise real estate', International Journal of Social Economics, 29(4), 299-314.

Walters, M. and Kent, P. (2000) 'Institutional economics and property, strata title — a survey and case study', Journal of Property Research, 17(3), 221-240.

Wan, H.H.Y., Ho, D.C.W. and Yau, Y. (2006) 'Effects of management bodies on the building management quality of private residential buildings in Hong Kong', Surveying and Built Environment, 17(2), 73-77.

Wong, S.K., Cheung, A.K.C., Yau, Y., Ho, D.C.W. and Chau, K.W. (2006) 'Are our residential buildings healthy and safe? A survey in Hong Kong', Structural Survey, 24(1), 77-86.

Yau, Y. (2008) 'Building conditions in Yau Tsim Mong, Hong Kong: appraisal, exploration and estimation', Journal of Building Appraisal, 3(4), 319-329.

Yip, N.M. and Forrest, R. (2002) 'Property owning democracies? Home owner corporations in Hong Kong', Housing Studies, 17(5), 703-720.

Yiu, C.Y. (2007) 'Building depreciation and sustainable development', Journal of Building Appraisal, 3(2), 97-101.

Zimring, C.M. and Reizenstein, J.E. (1980) 'Post-occupancy evaluation: an overview', Environment and Behavior, 12(4), 429-450. 